\title{
ARMOUR PLATES FROM KOZLOV ROB - ANALYSES OF TWO UNUSUAL FINDS
}

\author{
OKLEPNI PLOŠČI S KOZLOVEGA ROBA - ANALIZE DVEH \\ NENAVADNIH NAJDB
}

\author{
Tomaž Lazar¹, Primož Mrvar², Martin Lamut ${ }^{3}$, Peter Fajfar ${ }^{2}$ \\ ${ }^{1}$ National Museum of Slovenia, Prešernova cesta 20, 1000 Ljubljana, Slovenia \\ ${ }^{2}$ University of Ljubljana, Faculty of Natural Sciences and Engineering, Department of Material Science and Metallurgy, Aškerčeva cesta 12 , \\ 1000 Ljubljana, Slovenia \\ ${ }^{3}$ Slovenian centre of excellence for space sciences and technologies, Aškerčeva cesta 12, 1000 Ljubljana, Slovenia \\ peter.fajfar@omm.ntf.uni-lj.si \\ Prejem rokopisa - received: 2015-07-30; sprejem za objavo - accepted for publication: 2015-10-13
}

doi: $10.17222 / \mathrm{mit} .2015 .242$

During archaeological excavations of the fortifications on Kozlov rob, two perforated steel plates were discovered, the purposes of which had never been explained satisfactorily. Detailed examinations and scientific analyses confirmed that in one case at least we were dealing with fragments of armour from the late Middle Ages or the early Modern Period that had later been reworked into an entirely unrelated object having, in all possibility, a non-warlike function.

Keywords: armour, weapons, archaeometallurgy, metallography, nano-indentation, Kozlov rob

Med arheološkimi izkopavanji utrdbe na Kozlovem robu sta bili odkriti dve preluknjani, jekleni plošči, katerih namembnost ni bila nikoli zadovoljivo pojasnjena. Natančne preiskave in znanstvene analize so potrdile, da gre v vsaj enem primeru za fragment oklepa iz poznega srednjega veka ali iz zgodnjega novega veka. Ta je bil naknadno predelan $\mathrm{v}$ predmet, ki po vsej verjetnosti ni služil vojaškemu namenu.

Ključne besede: oklep, orožje, arheometalurgija, metalografija nanovtiskovanje, Kozlov rob

\section{INTRODUCTION}

Kozlov rob is a lone hill of almost rectangular form reaching an altitude of $426 \mathrm{~m}$ above sea-level overlooking the town of Tolmin. Due to the strategic importance of the location, a castle was built on Kozlov rob in the $12^{\text {th }}$ Century. The castle remained in use until the mid-1 $17^{\text {th }}$ Century. ${ }^{1}$

Archaeological excavations at Kozlov rob were carried out in 1964/5 and 1996/7. The excavations revealed various finds. $^{2}$ As elsewhere in Central Europe, ${ }^{3,4,5}$ the finds consisted mostly of small, often fragmentary objects. Among those related to warfare, the largest group is represented by crossbow bolts. ${ }^{6}$ In addition to other fragments of arms and armour, two steel plates were found, both perforated with rows of holes. One of them was first reported on in 2008. ${ }^{1,7}$

The unclear purposes of the plates soon stimulated lively discussion. The first plate evidently represents the upper half of a breastplate. The second plate is made from much thicker steel sheet but lacks any recognisable features. The two fragments have little in common apart from the more or less symmetrically distributed holes. This is an indication that both objects had performed an identical function during their last period of working life. At least three hypotheses have been suggested as to their intended purpose:
1. Fragments of armour were used by the castle garrison for target practice with crossbows.

2. The perforated breastplate with vent holes is an example of extremely rare tournament armour for foot combat.

3. Worn-out fragments of armour were recycled and modified into something else, perhaps a grate or vent. In 2010 the plates from Kozlov rob were submitted to in-depth research for the first time. Four small samples were removed from each plate and subjected to metallographic analysis. The results indicated that both plates were made from relatively high-quality steel containing approximately $0.3 \%$ to $0.8 \%$ carbon with a ferritic-pearlitic structure. ${ }^{8,9}$

These preliminary results underlined the need for additional analyses and a more detailed publication about the plates from Kozlov rob. The following paper has been compiled to present a comprehensive overview of the analytical methods used as well as an interdisciplinary discussion of the latest findings.

\section{EXPERIMENTAL PART}

The fragment of breastplate No. 1 (Figure 1) is heavily corroded. It represents the upper half of a steel cuirass reaching up to the folded rim of the neck and armpit cut-out. The fragment originally belonged to a 


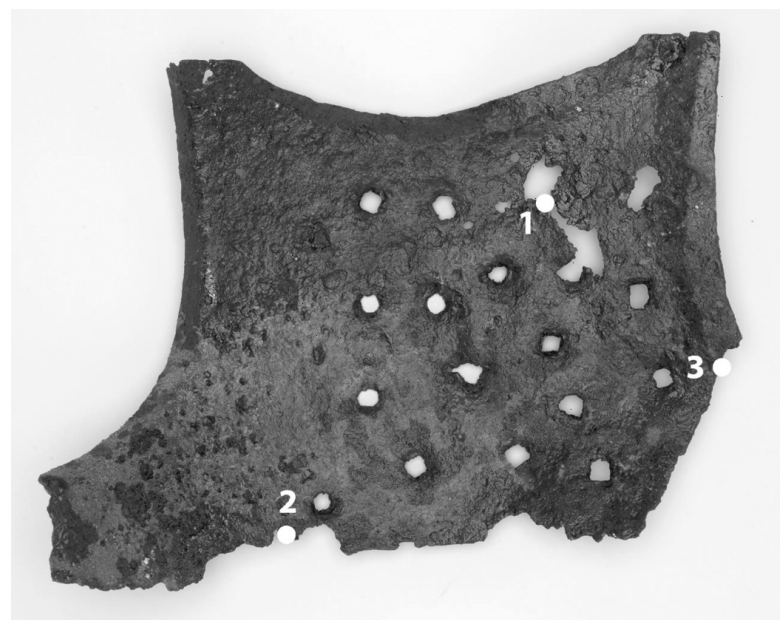

Figure 1: Fragment of breastplate showing the locations of the samples (Photo: T. Lazar), Goriški muzej, Nova Gorica, s. n.

Slika 1: Odlomek prsne plošče z mesti odvzema vzorcev (foto: T. Lazar), Goriški muzej, Nova Gorica, s. n.

breastplate of comparatively plain construction, possibly of North Italian manufacture, in the style typical for the period around $1500 \mathrm{AD} .^{8,10}$ It is made from one piece of steel sheet, approximately $1.5 \mathrm{~mm}$ to $3 \mathrm{~mm}$ thick. The length of the plate is $252 \mathrm{~mm}$, the width is $286 \mathrm{~mm}$, and its weight is $778 \mathrm{~g}$. Due to a progressive state of corrosion, the original thickness of the sheet metal is difficult to measure precisely, but can be estimated at around $2 \mathrm{~mm}$ on average. The convex-shaped steel sheet is perforated along two thirds of its width on the right-hand side with 18 holes arranged in more or less symmetrical rows. The holes are mostly of uniform, square shaped, pierced from the inner side of the breastplate. ${ }^{1,9}$

The fragment of steel plate No. 2 (Figure 2) is shaped as an irregular parallelogram. It is made from a massive steel sheet with a multi-layered anisotropic microstructure. The plate is perforated with 16 square and

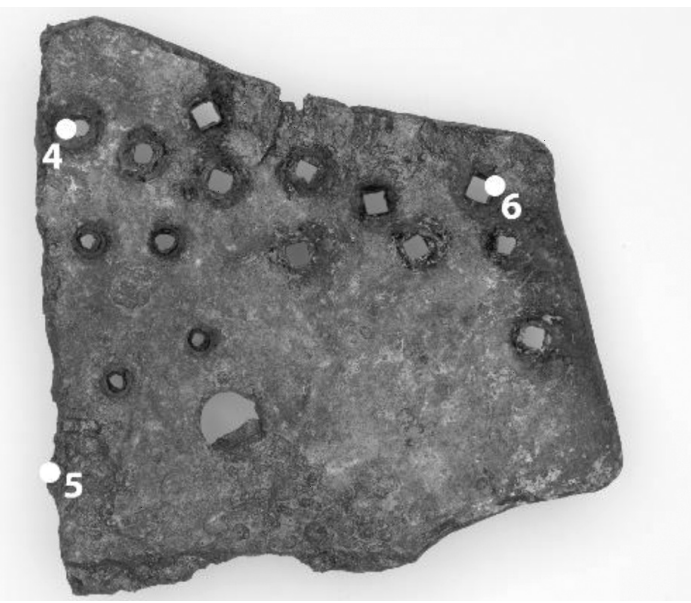

Figure 2: Fragment of steel plate showing the locations of the samples (Photo: T. Lazar), Goriški muzej, Nova Gorica, s. n.

Slika 2: Odlomek jeklene plošče z mesti odvzema vzorcev (Photo: T. Lazar), Goriški muzej, Nova Gorica, s. n. round holes pierced from both sides. Due to advanced corrosion the metal sheet has largely disintegrated longitudinally into multiple layers. The surface is covered with a thick layer of corrosion products. The thickness of the steel sheet is approximately $3.5 \mathrm{~mm}$ to $7 \mathrm{~mm}$, with an average of around $4.5 \mathrm{~mm}$. The length of the plate is $245 \mathrm{~mm}$, the width $244 \mathrm{~mm}$, and its weight is $1.504 \mathrm{~g}$. ${ }^{8,9}$

For the microstructural characterization and the mechanical analysis three small samples were removed from each steel plate. The locations of the samples of fragment No. 1 are shown in Figure 1, and their shapes are shown in Figure 3, and the locations of the samples of fragment No. 2 are shown in Figure 2, and their shapes are shown in Figure 4. The obtained samples were embedded in resin, ground, polished and etched using a solution of $2 \%$ nital. The microstructural characterization was performed using light optical microscopy (Olympus Microscope BX61). The tests for mechanical analysis were conducted on an Agilent G200 Nanoindenter using the continuous stiffness measurement (CSM) option. The CSM technique allows the contact stiffness together with the projected area of hardness impressions to be measured at any point along the loading curve. ${ }^{11,12}$ This instrument monitors and records the dynamic load and displacement of the indenter during indentation with a force resolution of approximately $50 \mathrm{nN}$ and a displacement resolution of approximately $0.01 \mathrm{~nm}$.

\section{RESULTS}

\subsection{Metallographic analysis}

Sample 1 originates from the edge of a heavily corroded hole. The examined surface runs along the plane of the plate. The sample is corroded, hence the microstructure of the metal is invisible on the macro photograph (Figure 3a). Sample 2 was removed from the lower, broken part of the plate. The examined surface

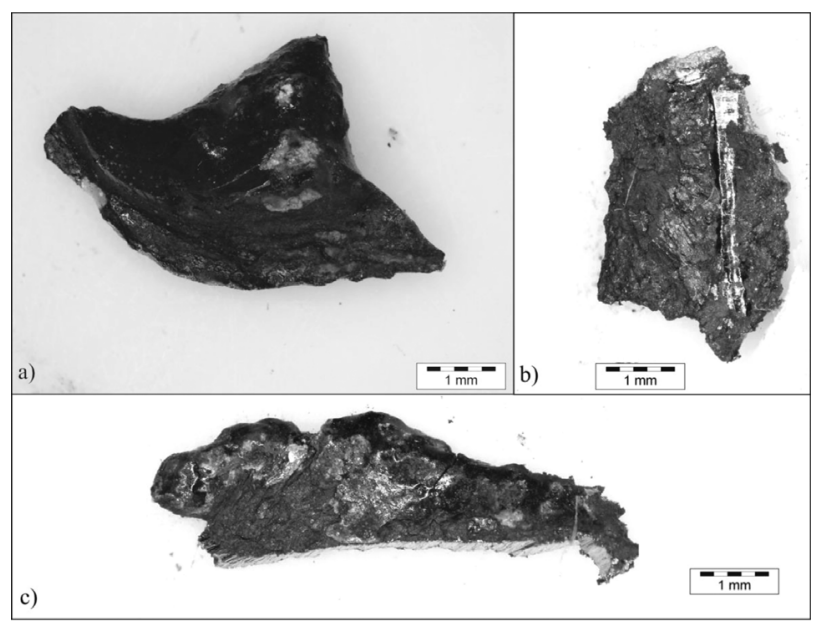

Figure 3: Samples from the plate No. 1: a) sample 1, b) sample 2, c) sample 3

Slika 3: Vzorci plošče št. 1: a) vzorec 1, b) vzorec 2, c) vzorec 3 


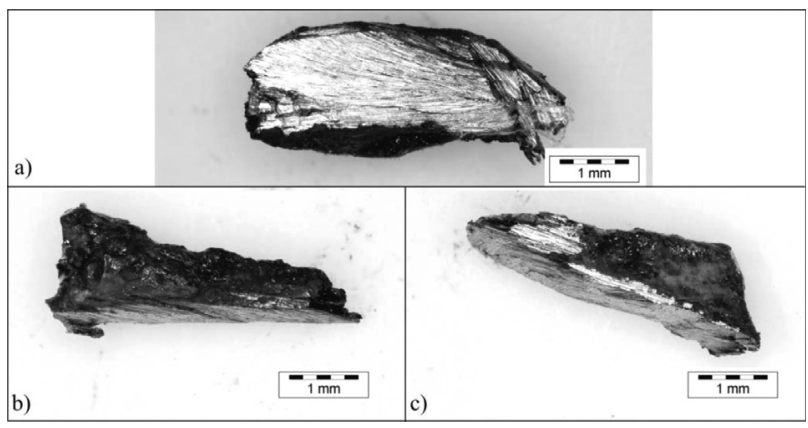

Figure 4: Samples from plate No. 2: a) sample 4, b) sample 5, c) sample 6

Slika 4: Vzorci plošče št. 2: a) vzorec 4, b) vzorec 5, c) vzorec 6

runs perpendicular to the plane of the plate (Figure 5). The microstructure contains mostly pearlite (darker microstructural areas of the grain) with a small proportion of ferrite (white microstructural areas). On the lower edge of the sample the grain is finely formed within a directional structure. Also, the proportion of ferrite is markedly larger. The dark area along the left edge represents the corroded surface. Sample 3 was taken from the right edge of the plate. The examined surface runs along the plane of the plate (Figure 6). The microstructure contains mostly pearlite with a small proportion of ferrite. On the upper edge of the sample (the outside edge of the plate) the grain is smaller and the proportion of ferrite larger. The dark area around the right edge represents the corroded surface. The existing corrosion products are formed mostly on the basis of $\mathrm{Fe}_{2} \mathrm{O}_{3}$ and $\mathrm{Fe}_{3} \mathrm{O}_{4}$

Within the narrow band along the lower right edge, the microstructure of sample 2 is directed along the flow of material produced during the perforation process (Figure 5). The grain is plastically deformed, non-recrystallized, as is typical of cold working. Given that the edge layers contain a significantly higher portion of recrystallized ferrite grain, it can be estimated that the
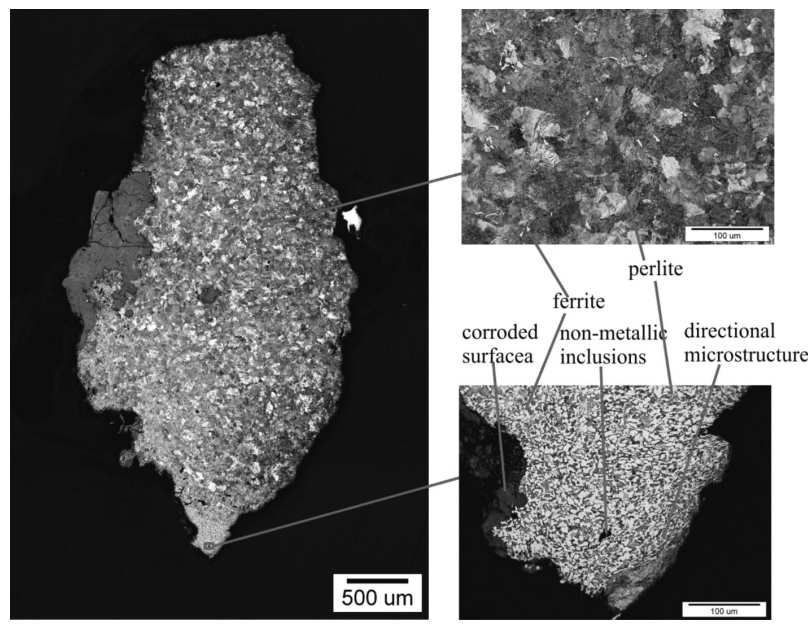

Figure 5: Sample 2, plate No. 1 Slika 5: Vzorec 2, plošča št. 1

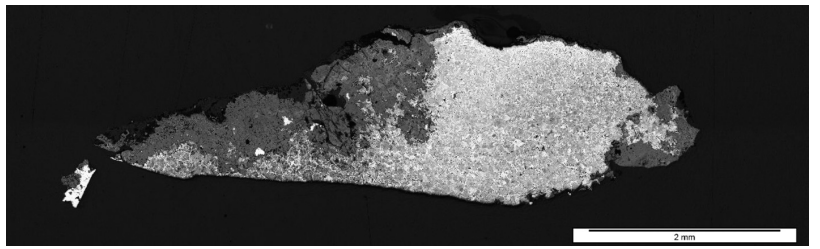

Figure 6: Sample 3, plate No. 1

Slika 6: Vzorec 3, plošča št. 1

steel plate was heated to a temperature between $700{ }^{\circ} \mathrm{C}$ and $900{ }^{\circ} \mathrm{C}$ prior to the perforation process. At that temperature and a suitable time of heating the steel plate was partly decarburised on the surface. This is confirmed by the microstructure containing an increased proportion of ferrite. The narrow band of non-recrystallized grain may have been formed during a later repair of the hole done cold.

Sample 4 originates from the edge of a round hole. The examined surface runs perpendicularly along the plane of the plate (Figure 7). In the centre of the sample the microstructure contains mostly pearlite with a small proportion of ferrite. In the outer layers the grain is formed more finely and there is an increased content of ferrite. Sample 5 was removed from the left edge of the plate. The examined surface runs perpendicular to the plane of the plate (Figure 8). Along the entire crosssection pearlite can be observed, indicating that the steel has a composition containing $0.8 \%$ carbon. Sample 6 was taken from the edge of a square hole. The examined surface runs perpendicular to the plane of the plate (Figure 9). The microstructure is fine grained, containing pearlite and ferrite. The edges of the sample contain ferrite and the grain is larger, too.

The microstructure of sample 5 is predominantly pearlitic. The examined surface is directed towards the interior of the plate. Such a microstructure is typical of hot working. The micro photographs demonstrate that

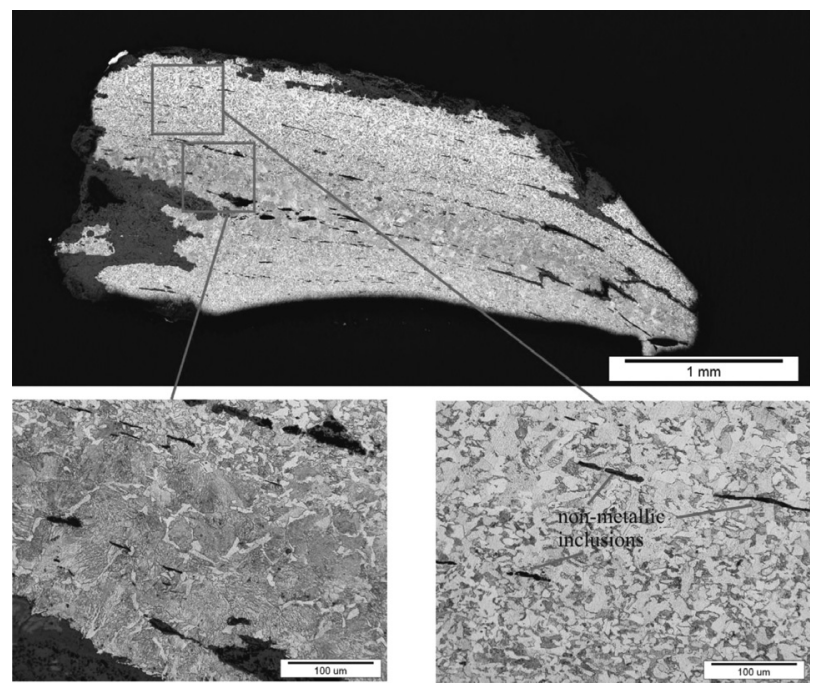

Figure 7: Sample 4, plate No. 2

Slika 7: Vzorec 4, plošča št. 1 


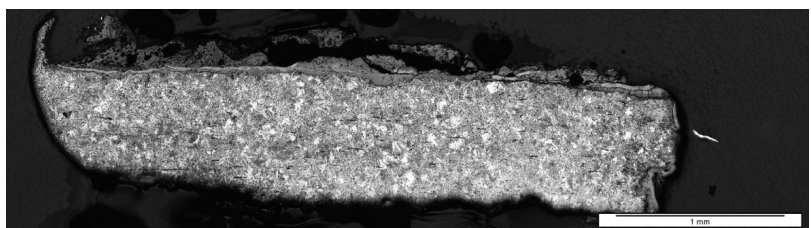

Figure 8: Sample 5, plate No. 2

Slika 8: Vzorec 5, plošča št. 1

the plate was formed by hot forging, then slowly air cooled. The holes on the second plate were punched hot as well. This is confirmed by the compositions of samples 4 and 6 that contain fine-grained microstructures with an increased ferrite content in the outer layers, which are partly decarburised. The grain is larger than is the case with the first plate. The proportion of ferrite is larger, too. Assuming that both plates were heated to the same temperature during the manufacture, the larger grain size may be attributed to a longer heating time, as plate No. 2 is twice as thick as No. 1 .

The examined samples also contain non-metallic inclusions that were oriented perpendicularly to the direction of deformation during the sequences of hot forging. ${ }^{13,14}$

Figure 7 demonstrates that these inclusions are relatively soft and therefore were deformed considerably.

\subsection{Mechanical analysis}

In order to obtain a deeper insight into the origin of the archaeological finds in the form of two perforated steel plates it was decided to obtain some mechanical data. Since the archaeologists and museum curators are not in favour of any material being detached from museum objects, the amount material to work with is usually fairly small, hence it is difficult to extract its mechanical properties. Due to such constraints the nanoindentation technique was used, which can provide a Young's modulus and a hardness from very small samples.

The penetration depth of $1 \mu \mathrm{m}$ was carefully chosen in order to avoid the influences of the indentation size effect, the surface roughness or the surface inclination and to reach a constant value or plateau region. At each

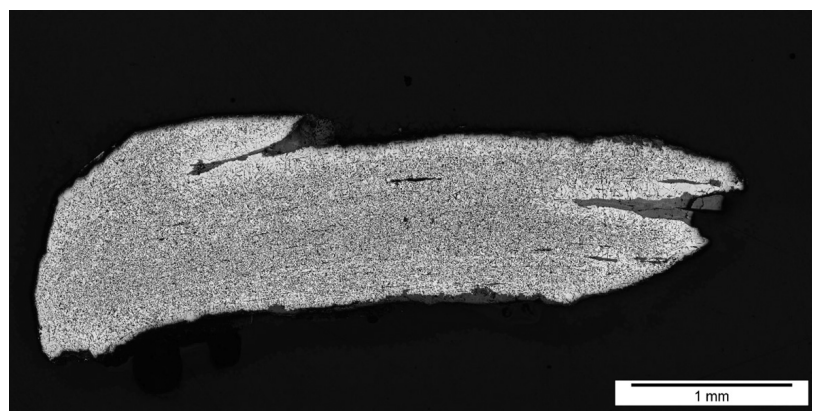

Figure 9: Sample 6, plate No. 2

Slika 9: Vzorec 6, plošča št. 1

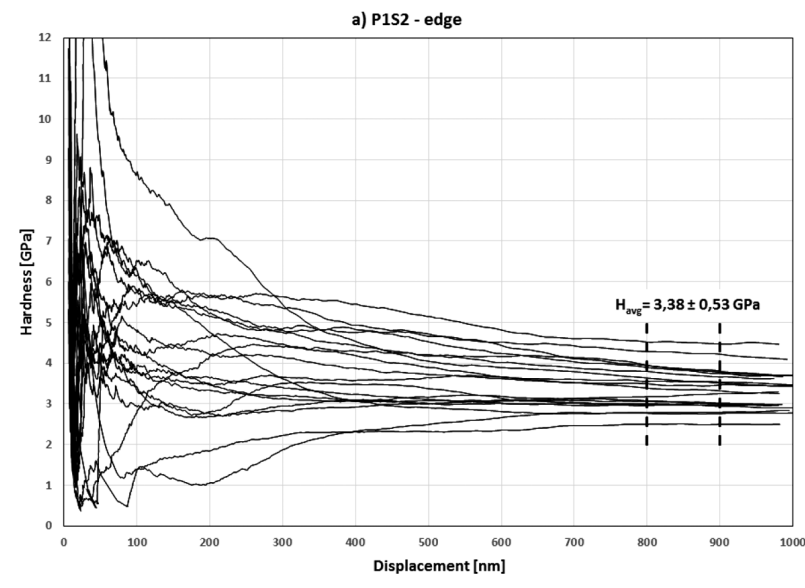

b) P1S2 - middle

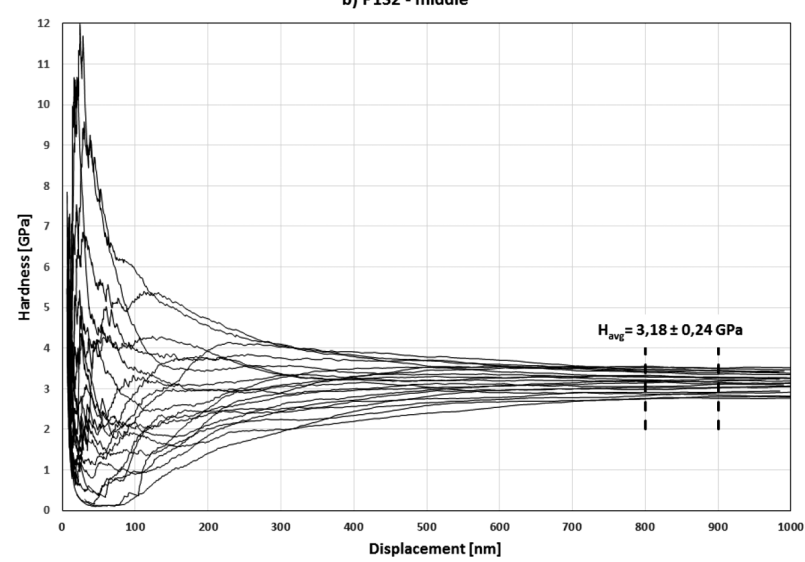

Figure 10: Hardness as a function of contact depth for P1S2: a) the edge and $b$ ) the middle

Slika 10: Trdota v odvisnosti od kontaktne globine za P1S2: a) rob in b) sredina

point at least 6 measurements were taken. In spots where the results showed extensive dissipation, the number of measurements was increased considerably.

The first point of interest was plate No. 1, sample 2 (P1-S2), removed from the area next to a hole, where at the edge finely formed grains are found with an increased portion of ferrite and in the middle part larger grains with a predominantly pearlitic microstructure. The results are presented in Table $\mathbf{1}$. In order to eliminate point fluctuations in the load-displacement curve the values are averages at depths between $800 \mathrm{~nm}$ and $900 \mathrm{~nm}$ from each test. (Note that for the nanoindentation range the hardness values are greater than for the micro or macro scale $\left.{ }^{11,12}\right)$. The hardness measurements of P1-S2 (Figure 10) show a large dissipation at the edge in comparison to the area in the middle. It shows a slightly larger mean hardness (Table 1), but considering the dissipation it all falls into the margin of error. Since ferrite has a smaller hardness than pearlite it is assumed that the influence of cold-worked smaller grains is minimized by a greater ferrite share in the microstructure. Furthermore, the tests were made separately at the ferritic and pearlitic grains, but the results overlapped, most likely due to effects from adjacent grains, so it was 
hard to draw any sound conclusions. Sample 3 (P1-S3), taken away from the afterwards induced holes, shows a considerably smaller hardness. The grains remained in the original state and no plastic deformation occurred, which agrees well with the above hypothesis.

Table 1: Hardness tests statistics on the first plate

Tabela 1: Statistika preizkusov trdote za prvo ploščo

\begin{tabular}{|c|c|c|c|}
\hline & P1-S2 middle & P1-S2 edge & P1-S3 \\
\hline Mean & 3.18 & 3.38 & 2.29 \\
\hline Std. Dev. & 0.24 & 0.53 & 0.15 \\
\hline \% COV & 7.48 & 15.82 & 6.36 \\
\hline
\end{tabular}

In Table 2 the hardness results from plate No. 2 are given. Samples 4 and 6 (P2-S4, P2-S6), taken from the vicinity of a hole, show higher hardness where the grains are smaller with a lower share of ferrite, which in these cases is in the middle of the samples. Where the grains are larger and a higher share of ferrite is observed, the hardness is lower, comparable with the samples P1-S3 and P2-S5, taken from the area with no subsequent reworking of the plates.

Table 2: Hardness tests statistics on the second plate Tabela 2: Statistika preizkusov trdote za drugo ploščo

\begin{tabular}{|c|c|c|c|c|c|}
\hline & $\begin{array}{c}\text { P2-S4 } \\
\text { middle }\end{array}$ & $\begin{array}{c}\text { P2-S4 } \\
\text { edge }\end{array}$ & P2-S5 & $\begin{array}{c}\text { P2-S6 } \\
\text { middle }\end{array}$ & $\begin{array}{c}\text { P2-S6 } \\
\text { edge }\end{array}$ \\
\hline Mean & 3.05 & 2.69 & 2.82 & 2.97 & 2.57 \\
\hline Std. Dev. & 0.08 & 0.09 & 0.3 & 0.3 & 0.23 \\
\hline \% COV & 2.56 & 3.24 & 10.53 & 10.1 & 9 \\
\hline
\end{tabular}

\section{DISCUSSION}

Fragments of armour were used by the castle garrison for target practice with crossbows.

Both steel plates are perforated with holes, mostly of a square shape, measuring approximately $10 \mathrm{~mm} \times 10 \mathrm{~mm}$ (Figures 11 and 12). Such dimensions correspond to the typical late-medieval crossbow bolt with a square- or diamond-shaped head. A sizeable group of bolt heads of

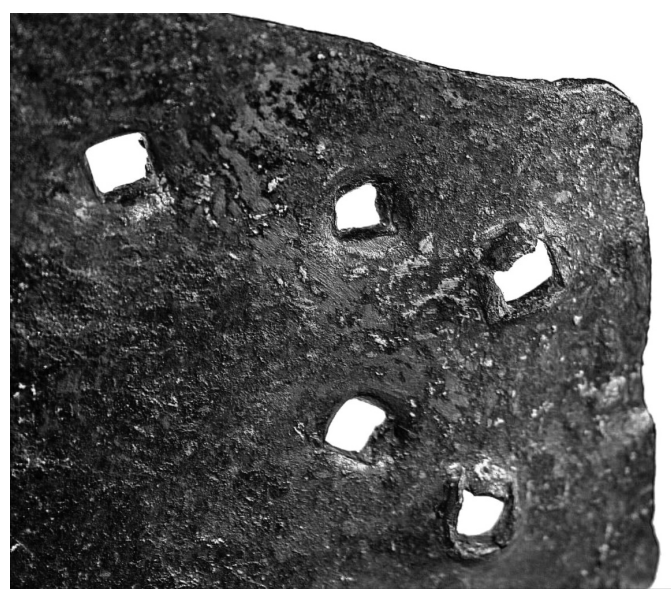

Figure 11: Square-shaped holes of plate No. 2 (Photo: D. Todorović) Slika 11: Luknje kvadratne oblike na plošči št. 2 (foto: D. Todorović) that same type was unearthed on Kozlov $\operatorname{rob}^{6,7}$, seemingly supporting the idea that the plates had been used for marksmanship practice.

However, several arguments speak against such an explanation. On both plates the holes are placed quite neatly in straight rows. Such precise shot placement would be difficult to achieve even by a skilled marksman. At any rate, the arrangement of holes is much more symmetrical than might be expected from a random dispersion of hits.

The penetration of late medieval crossbows should not be overestimated. The spanning force of a "one-foot" military crossbow was within the range of $1500 \mathrm{~N}$, or $2100 \mathrm{~N}$ in the case of the heavier "two-foot" type. In the $15^{\text {th }}$ century, even more powerful crossbows were developed with draw weights up to 5000 N. ${ }^{16-20}$ However, their efficiency was low. At point-blank range, the maximum penetration of a typical crossbow bolt weighing 70 $\mathrm{g}$ might reach up to $60 \mathrm{~mm}$ of pinewood. Documented cases of projectiles stuck within the wooden structures of medieval castles show a degree of penetration averaging only $20 \mathrm{~mm}$ in seasoned softwood. ${ }^{16}$

The kinetic energy of a crossbow bolt ${ }^{21}$ at point-blank range may be estimated at around $200 \mathrm{~J} .{ }^{16}$ The latter is clearly superior to a yew longbow with a kinetic energy of $120 \mathrm{~J}$ at a draw weight of $670 \mathrm{~N} .{ }^{22}$ However, it would be barely sufficient to penetrate even the relatively thin plate No. 1. The second plate, at least twice as thick, would prove entirely resistant to crossbow bolts. In fact, it would be proof against a musket ball possessing at least ten times greater kinetic energy. ${ }^{23}$

Therefore, it seems highly unlikely that the two steel plates from Kozlov rob were pierced by crossbow bolts. The final answer is provided by the metallographic analysis. Had the holes been made by the impact of crossbow bolts the samples would show evidence of mechanical deformation and cold work hardening of the microstructure.

The perforated breastplate with vent holes is an example of extremely rare tournament armour for foot combat.

In the late Middle Ages, new types of armour were developed specifically for tournament use. The famous

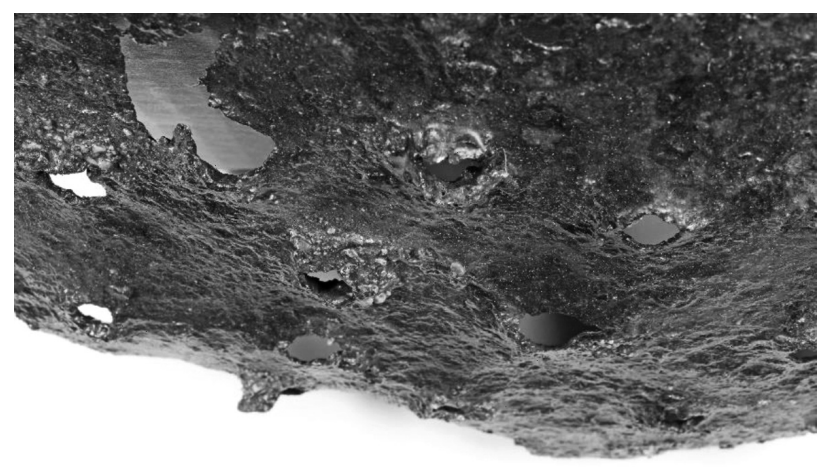

Figure 12: Holes on plate No. 1 (Photo: T. Lazar)

Slika 12: Luknje na plošči št. 1 (foto: T. Lazar) 


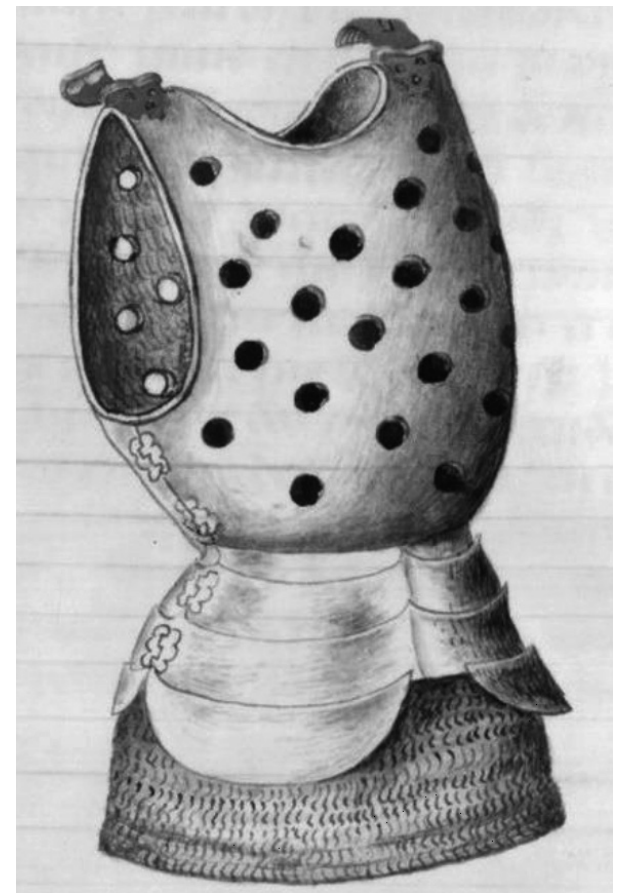

Figure 13: Armour for foot combat as depicted in René of Anjou's tournament book (Bibliothèque Nationale, Paris, MS Fr 2695, fol. 25v)

Slika 13: Oklep za pehotni dvoboj iz turnirske knjige Renéja Anžujskega (Bibliothèque Nationale, Paris, MS Fr 2695, fol. 25v)

tournament book of René of Anjou from ca. 1460 depicts a cuirass with numerous vent holes for fighting on foot (Figure 13). ${ }^{24,25}$ Recent archaeological excavations at the Haus Herbede in the Ruhr district have revealed a breastplate of the exact same type. ${ }^{26,27}$ The discovery of a perforated breastplate at Kozlov rob gave rise to speculation

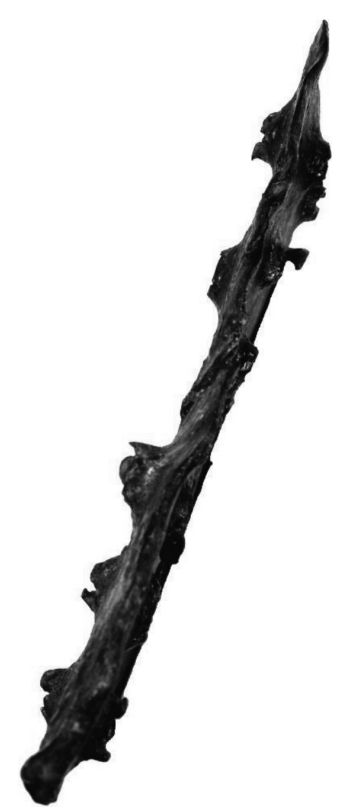

Figure 14: Side view of plate No. 2 (Photo: D. Todorović) Slika 14: Stranski pogled plošče št. 2 (foto: D. Todorović) that it might have belonged to a similar suit of tournament armour designed to prevent overheating. ${ }^{1,7}$

Nonetheless, a closer examination of the breastplate disproved such a possibility. The holes are crudely made, which is clearly inconsistent with the workmanship of late-medieval tournament armour. At any rate, the breastplate would be very uncomfortable to wear due to the sharp perforations. The second perforated plate is an even less sophisticated product. The holes were struck into the steel sheet from both sides, in many cases, forming crude bulges up to a centimetre deep. Such a plate could never have belonged to armour worn on one's person (Figure 14).

Worn-out fragments of armour were recycled and reworked into something else, perhaps a grate or vent.

Steel was an expensive commodity in the past, hence recycling of old or damaged steel products was part of everyday life. Provided that a damaged fragment of armour had to be scrapped, it seems plausible that it was reworked into a new product, even something as mundane as a fireplace grate or a vent. Two very similar plates used for that purpose were spotted coincidentally in 2010 , built into a modern brick structure on the island of Rab (Figures 15a and 15b).

The perforations on the plates were clearly made using a massive chisel or punch. Due to the thickness of the metal sheet, particularly on plate No. 2., it can be

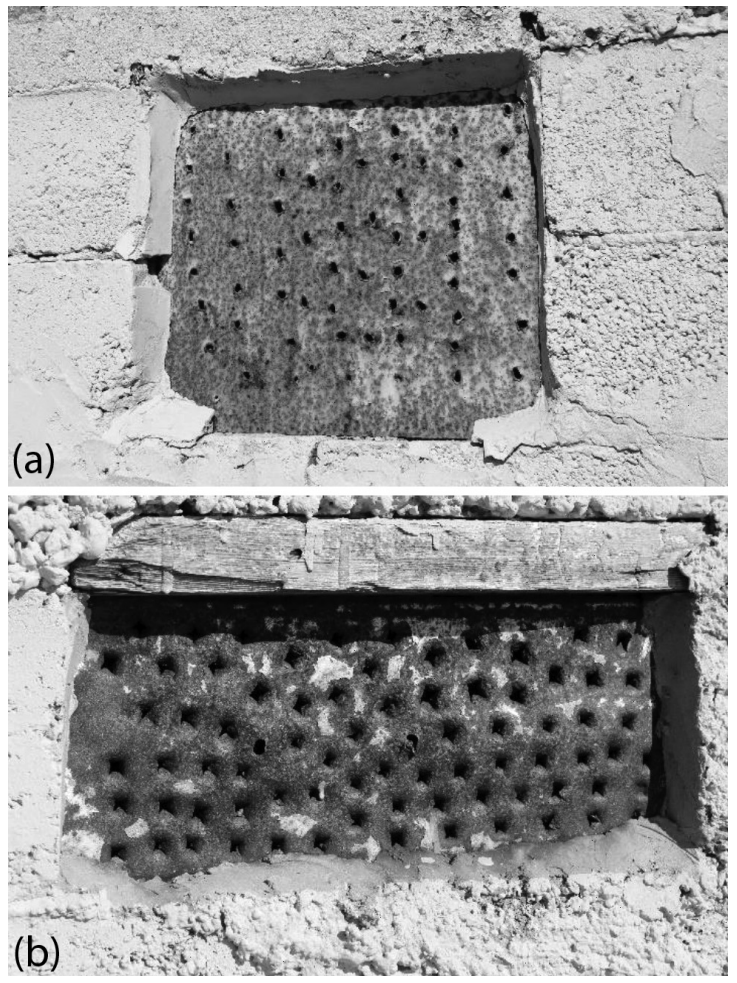

Figure 15: a), b): Unexpected analogy from the Adriatic coast: two simple steel vents, designed in the same manner, built into a modern outbuilding on the island Rab (Photo: T. Lazar)

Slika 15: a), b): Nepričakovana podobnost z Jadranske obale: dva preprosta jeklena zračnika, oblikovana na enak način in vgrajena $\mathrm{v}$ moderno zgradbo na otoku Rab (foto: T. Lazar) 
assumed that the punching was performed while the plate was heated in a forge. Even so, the process would have necessitated heavy hammer blows, causing severe deformation of the material. Further explanation of the work process may be provided by scientific analyses, in particular metallography. ${ }^{13,14,28,29}$

\section{CONCLUSION}

The fragmentary breastplate No. 1 was a quality product made of steel with a relatively high carbon content. ${ }^{16}$ The latter also holds true for plate No. 2, even though, based on its shape alone, it is impossible to determine what sort of object it had belonged to originally. One cannot exclude the possibility that it was merely a steel semi-product. ${ }^{8}$

The results of the metallographic analyses proved that both plates had been reworked in a similar manner. As could be expected given the technological capabilities of the pre-industrial era, the holes were made by hot punching. Only later on, as indicated by the non-recrystallization, the directional structure of the part of sample 2 (Figure 5), some of the holes may have been repaired or reworked slightly by cold working. The mechanical analyses show that in the case of small samples the nanoindentation technique can provide useful additional data. The results confirm the metallographic analyses and further reveal the material properties as well as the methods of making and processing the plates.

Based on the above observations, it is clear that once the holes had been punched and formed, at least plate No. 1 was not exposed to temperatures in excess of approximately $400{ }^{\circ} \mathrm{C}$ that would have caused recrystallization of the cold-worked areas. Therefore, it is possible to conclude that the perforated plates were most likely used as simple grates, vents or were put to some other similar uses.

The reworking of the steel plates seems all the more plausible considering the gradual decline of armour in Europe during the $17^{\text {th }}$ century. From that standpoint it might be easier to understand why on Kozlov rob a breastplate was reworked into a new product, no longer having anything in common with the armour's original purpose.

\section{REFERENCES}

${ }^{1}$ B. Žbona Trkman, F. Bressan, Orožje z gradu Kozlov rob; Vojske, orožje in utrdbeni sistemi v Posočju, Tolminski muzej, Tolmin 2008, 58

${ }^{2}$ B. Žbona Trkman, A. Kruh, Stanje raziskav gradov in dvorcev na območju historične Goriške I. Dobrovo, Kozlov rob, Rihemberk, Štanjel, Goriški letnik, Nova Gorica, 33-34 (2010), 195-217

${ }^{3}$ K. Predovnik, Trdnjava Kostanjevica na Starem gradu nad Podbočjem, Filozofska fakulteta, Ljubljana 2003, 240

${ }^{4}$ C. Krauskopf, Plemstvo in predmeti iz njegovega vsakdanjika. Raziskave materialne kulture 13. in 14. stoletja, Arheo, Ljubljana, 23 (2005), 47-62
${ }^{5}$ T. Lazar, Bojišča visokega in poznega srednjega veka kot izziv slovenski arheologiji, Arheo, Ljubljana, 28 (2011), 119-130

${ }^{6}$ F. Bressan, Le cuspidi di freccia nel Friuli medievale, Università degli Studi di Trieste, Trieste 1996, 275

${ }^{7}$ T. Lazar, Vojaška zgodovina slovenskega ozemlja od 13. do 15 . stoletja, Filozofska fakulteta, Ljubljana 2009, cat. no. M 315-346, 442

${ }^{8}$ A. Williams: Metalurške značilnosti poznosrednjeveških oklepov iz srednje Evrope, Vitez, dama in zmaj; Dediščina srednjeveških bojevnikov na Slovenskem, 1, Razprave, Ljubljana 2011, 233-247

${ }^{9}$ T. Lazar, T. Nabergoj, P. Bitenc, Vitez, dama in zmaj; Dediščina srednjeveških bojevnikov na Slovenskem. 2, Katalog predmetov, Narodni muzej Slovenije, Ljubljana 2013, cat. no. 256, 257

${ }^{10}$ J. Mann, Wallace Collection Catalogues, European Arms and Armour, Vol I., Armour, The Trustees of the Wallace Collection, London 1962, cat. no. A 214

${ }^{11}$ W. C. Oliver, G. M. Pharr, An Improved Technique for Determining Hardness and Elastic Modulus Using Load and Displacement Sensing Indentation Experiments, J. Mater. Res., 7 (1992), 1564-1583, doi:10.1557/JMR.1992.1564

${ }^{12}$ R. Rodríguez, I. Gutierrez, Correlation Between Nanoindentation and Tensile Properties. Influence of the Indentation Size Effect, Materials Science and Engineering, A361 (2003), 377-384, doi:10.1016/S0921-5093(03)00563

${ }^{13}$ M. Nečemer, T. Lazar, Ž. Šmit, P. Kump, B. Žužek, Study of the Provenance and Technology of Asian Kris Daggers by Application of X-Ray Analytical Techniques and Hardness Testing, Acta Chim. Slov., 351 (2013) 60, (2), 351-357

${ }^{14}$ Fajfar, J. Medved, G. Klančnik, T. Lazar, M. Nečemer, P. Mrvar, Characterization of a Messer - the late-Medieval single-edged sword of Central Europe, Materials Characterization, 86 (2013), 232-241, doi:10.1016/j.matchar. 2013.10.005

${ }^{15}$ E. Duka, H. Oettel, T. Dilo, Connection Between Micro and Macro Hardness. Pearlitic-Ferritic Steel, AIP Conference Proceedings 1476, 2012, 47-5, doi:10.1063/1.4751563

${ }^{16}$ E. Harmuth, Die Armbrust, Akademische Druck- und Verlaganstalt, Graz 1986, p. 232

${ }^{17}$ W. F. Paterson, A Guide to the Crossbow, Society of Archer-Antiquaries, Burnham 1990, 132

${ }^{18}$ J. Alm, European Crossbows, Royal Armouries, Leeds 1996, 25

${ }^{19}$ J. Liebel, Springalds and Great Crossbows, Royal Armouries, Leeds 1998, 23

${ }^{20}$ H. Richter, Die Hornbogenarmbrust, Hoernig Angelika, Ludwigshafen 2006, 190

${ }^{21}$ A. Williams, The Knight and the Blast Furnace, Brill, Leiden, Boston 2003, 954

${ }^{22}$ M. Strickland, R. Hardy, The Great Warbow; From Hastings to the Mary Rose, Sutton, Stroud 2005, 538

${ }^{23}$ P. Krenn, Von alten Handfeuerwaffen, Landeszeughaus, Graz 1989, 149

${ }^{24}$ Bibliothèque Nationale, Paris, MS Fr 2695

${ }^{25}$ J. Heers, F. Robin, René d'Anjou, Traité des Tournois, Lengenfelder, München 1993, 30

${ }^{26}$ H. W. Peine, 2004: Ein Blick in die Waffenkammer des Hauses Herbede an der Ruhr, Das Brigantinen-Symposium auf Schloss Tirol/Il simposio sulla brigantina a Castel Tirolo, Innsbruck, 2004, 51-53

${ }^{27}$ C. Blair, European Armour, B. T. Batsford Ltd., London 1958, 248

${ }^{28}$ D. A. Scott, Metallography and Microstructure of Ancient and Historic Metals, The J. Paul Getty Trust, Los Angeles 1991, 155

${ }^{29}$ T. Lazar, N. Nemeček, Interdisciplinary Research of Museum Objects. Practical Experience with Various Analytical Methods, RMZ: Materials and geoenvironment, 60 (2013) 4, 249-261 